\title{
ANALYSIS OF ANTIBIOTICS USE IN PEDIATRIC PNEUMONIA PATIENTS AGED 3 MONTHS - 5 YEARS
}

\author{
Dhita Evi Aryani ${ }^{1}$, Didik Hasmono ${ }^{2}$, Nun Zairina ${ }^{3}$, Landia Setiawan $^{4}$ \\ ${ }^{1}$ Master Program of Clinical Pharmacy, Universitas Airlangga, ${ }^{2}$ Faculty of Pharmacy, Universitas Airlangga, Surabaya \\ ${ }^{3}$ Pharmacy Installation, Dr Soetomo Hospital, Surabaya, ${ }^{4}$ Department of Pediatrics, Dr Soetomo Hospital, Surabaya
}

\begin{abstract}
ABSTRAK
Pneumonia adalah penyakit infeksi yang menyebabkan peradangan akut parenkim paru-paru dan pemadatan eksudat pada jaringan paru. Selain menyebabkan morbiditas dan mortalitas yang signifikan, pneumonia juga sulit didiagnosis, perawatan yang kurang tepat dan kurang dianggap serius. Pneumonia ini menyebabkan kematian 14\% balita di Indonesia, dengan angka kematian 83 balita per hari. Kesulitan untuk menegakkan diagnosis, pemilihan antibiotika yang kurang tepat, adanya efek samping obat, perbedaan farmakokinetik farmakodinamik obat dan resistensi akibat penggunaan antibiotika yang tidak bijak menjadi masalah tersendiri. Oleh sebab itu perlu dilakukan penelitian analisis penggunaan antibiotika pada pasien pneumonia anak usia 3 bulan - 5 tahun. Tujuan penelitian ini adalah untuk menganalisis penggunaan antibiotika pada pasien pneumonia anak usia 3 bulan - 5 tahun dengan metode kuantitatif DDD/100 patient-days dan kualitatif dengan metode Gyssens. Penelitian ini merupakan penelitian observasional dengan tipe kohort prospektif. Sampel penelitian adalah pasien anak (usia 3 bulan sampai 5 tahun) dengan diagnosis pneumonia yang mendapatkan antibiotika yang dirawat dalam rentang 8 Februari 2014 - 8 Mei 2014 yang memenuhi kriteria inklusi. Sampel yang memenuhi kriteria inklusi sebanyak 29 pasien dengan penggunaan antibiotika sebanyak 75 . Hasil analisis kuantitatif dengan metode DDD/100 patients days didapatkan nilai penggunaan antibiotika ampisilin 34,39DDD/100 patient days dan hasil analisis kualitatif menggunakan metode Gyssens didapatkan penggunaan antibiotika yang sudah sesuai (kategori 0) sebanyak 32\%. Dari hasil penelitian diketahui bahwa ampisilin paling sering digunakan yaitu sebesar 34,39 DDD/100 patient days. Dan dari analisis kualitatif hanya 32\% penggunaan antibiotika yang rasional. (FMI 2016;52:108-115)
\end{abstract}

Kata kunci: pneumonia, anak, DDD/100 patient-days, Gyssens

\begin{abstract}
Pneumonia is an infectious disease that causes acute inflammation of the lung parenchyma and compaction exudate in the lung tissue. In addition to causing significant morbidity and mortality, pneumonia is also difficult to diagnose, treatments are less precise and less taken seriously. Pneumonia caused the death of $14 \%$ of children under five in Indonesia, with a mortality rate of 83 children per day. The difficulty of diagnosis, the selection of a less appropriate antibiotics, side effects, differences in pharmacokinetics and pharmacodynamics of the drug in infants and antibiotics resistance is to be a problem in itself. Therefore it is necessary to study the analysis of the use of antibiotics in patients with pneumonia of children aged 3 months till 5 years. The aim of this research to analyze antibiotics therapy in patients with pneumonia of children aged 3 months till 5 years. Method: an observational cohort analysis was carried out in the Pediatrics Respirology Division Dr. Soetomo Hospital Surabaya. Data was collected from February to May 2014. Patients who met the inclusion criteria were observed prospectively and the quantity and quality of antibiotics usage assessed with Gyssens category. Result: from February to May 2014 period, prospectively, the antibiotics usage quantitative evaluation used DDD/patient days shows that ampicillin 34.39DDD/100 patient days. Qualitative evaluation using Gyssens category on 75 antibiotics therapy shows that 32\% considered appropriate. So, this study showed that ampicillin is most widely and qualitative analysis, only $32 \%$ of rational use of antibiotics. (FMI 2016;52:108-115)
\end{abstract}

Keywords: pneumonia, pediatric, antibiotics, gyssens category, DDD/100 patient days

Correspondence: Dhita Evi Aryani, Perum Taman Sigura-gura Estate Jl. Sunan Muria 7/27 Malang. Phone: 082225873336. e-mail: dhitaaryani2@gmail.com

\section{INTRODUCTION}

Pneumonia is an infectious disease that causes acute inflammation of the lung parenchyma and compaction exudate in the lung tissue. In addition to causing significant morbidity and mortality rates, pneumonia is also difficult to diagnose, lack of proper care and not to be taken seriously (Mandell \& Wunderick 2010). Based on the report regencies/cities in East Java, the number of pneumonia cases under five in 2010 amounted to 76745 cases $(78.81 \%$ of total cases of pneumonia). The condition occurs primarily in cases of malnutrition with unhealthy environmental conditions (Health Office 2010). In Dr. Soetomo Hospital (period January 2007December 2008) there are $66 \%$ of patients pneu-monia infant community with a mortality rate of $4 \%$ (Nata- 
prawira et al 2010, Purniti et al 2011, Setyoning-rum \& Setiawati 2011, Asih et al 2011). The magnitude of the incident showed this age group susceptible to pneumonia due to weak/incomplete immune system and in patients suffering from recurrent infections occurs as a result of a defect complex system of defense mechanisms (PrabhuDas et al 2011, Jesenak et al 2011).

Treatment given depends on the age, clinical condition and epidemiological factors (Said 2010). Management of patients with pneumonia include supportive therapy in the form of provision of food or fluids as needed as well as acid-base correction as needed. Given oxygen therapy routine, if the disease is severe enough, the breathing apparatus may be required especially in the first 24-48 hours. The most important part of the governance pneumonia is antibiotics are ideally matched to the germs that cause, but due to various constraints diagnostic etiology then all pneumonia patients given empiric antibiotics (Said 2010). Administration of antibiotics at the Department of Pediatrics, Dr. Soetomo Hospital, is adapted to the CO of the Division of Respirology.

For empirical therapy using amoxicillin, amoxicillin clavulanate, patients with pneumonia can be treated as outpatients, while therapy with ampicillin or ampicillin sulbactam for patients with pneumonia required hospitalization. And for patients with pneumonia who previously had been treated at another hospital could be given ampicillin-sulbactam if previously treated for less than 72 hours and could be given cefotaxime or ceftriaxone if previously treated more than 72 hours. For atypical pneumonia treatment using spiramycin, erythromycin, azithromycin or clarithromycin (Setiawati et al 2012).

Analysis of antibiotic use can be done with both qualitative and quantitative methods. Qualitative methods are performed with instruments Gyssen algorithm aims to evaluate and ensure the rational use of antibiotics, namely the right indication, right patient, right drug, right dose of the regimentation and guard against drug ESO. Quantitative methods and the measurement instrument DDD/100 patient-days aimed to evaluate the total amount of antibiotics consumed by the patient during care. Response to treatment can be defined clinical and laboratory. The clinical response appeared within 48-72 hours and is recommended not to change the treatment given, unless within that period the patient's condition deteriorates.

Clinical parameters include the number of leukocytes, oxygenation and body temperature, whereas microbiological parameters are the result of culture. Quantitative culture results obtained from the lower respiratory tract material before and after the therapy can be used to assess the microbiological resolution. Microbiological results can be bacterial eradication, superinfection, recurrent infection or persistent infection and resistance (Cincinnati Children's Hospital Medical Center in 2005, Said 2010, Bradley et al 2011).

Based on the description above, it is necessary to study antibiotic consumption and the quality of antibiotic use in patients with pneumonia of children (ages 3 months 5 years) at the Dr. Soetomo Hospital to provide an overview of consumption and quality of use. For pharmacists results of this study can be used to improve pharmacy services, especially in the management of the drug in patients with pneumonia of children.

\section{MATERIALS AND METHODS}

This research is a type of observational study with prospective cohort. In this study, researchers did not perform an action or degrading treatment or intervention that is different from the Clinical Practice Guidelines in Respirology Division of the Department of Pediatrics, Dr. Soetomo Hospital. The sample in this study is pediatric patients (ages 3 months to 5 years) with a diagnosis of pneumo-nia who received antibiotics were treated in a span of February 8, 2014 - May 8, 2014, the way the sampling is done by consecutive sampling. Each patient according to the inclusion criteria were included as a sample for further monitoring during treatment. The inclusion criteria were patients of children (aged 3 months to 5 years) with a diagnosis of pneumonia who received antibiotics were treated at Respirology Division, Department of Pediatrics, Dr. Soetomo Hospital, are willing to participate in this study.

Of 177 patients hospitalized at Respirology Division, Department of Pediatrics, Dr. Soetomo Hospital, there were 29 patients who met the inclusion criteria Table 1 shows the demographic data of children pneumonia patients who met the inclusion criteria which include gender of the patient, age, severity of disease, the status of the patient and how the patient was hospitalized. The percentage of patients with pneumonia in children aged 3 months - 5 years this is the boy that is a number of 16 patients $(55.17 \%)$. This patient was admitted to hospital with the highest severity was feebly that a number of 16 patients $(55.17 \%)$. Most patients were hospitalized at Respirology Division, Department of Pediatrics, Dr. Soetomo Hospital, is BPJS patients ie $23(79.31 \%)$ and most patients is how to sign their own come through IRD is a number of 17 patients $(58.62 \%)$. 
Table 1. Patients' demographic data

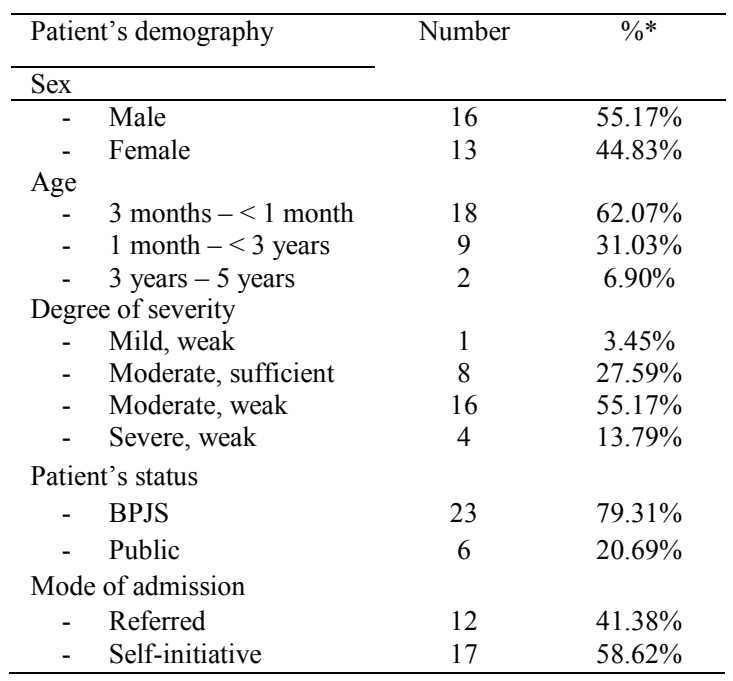

Types of pneumonia are the most common children ages 3 months-5 years during the study was bronchopneumonia amounted to $55.17 \%$ (Table 2). And most long hospitalization is less than 10 days (Table 3). For the distribution of comorbidities most is heart abnormalities that as many as 18 patients (Table 4). And to the use of empiric antibiotics given to patients with pneumonia of children described in Table 5. From the results of quantitative analysis by the number LOS 275 days showed that ampicillin has the greatest value, namely 34.39 DDD DDD/100 patient-days (Table 6). From the qualitative analysis showed that $32 \%$ is the rational use of antibiotics (Table 7). This means that the amount of antibiotic use not in accordance greater than appropriate.

Table 2. Types of penumonia

\begin{tabular}{lcc}
\hline Types of pneumonia & $\begin{array}{c}\text { Number of } \\
\text { patients }\end{array}$ & $\begin{array}{c}\text { Percentage } \\
(\%)^{*}\end{array}$ \\
\hline Bronchopneumonia & 16 & $55.17 \%$ \\
Pneumonia & 13 & $44.83 \%$ \\
\hline Total & 29 & 100 \\
\hline
\end{tabular}

Table 3. Length of hospitalization

\begin{tabular}{ccc}
\hline $\begin{array}{c}\text { Length of } \\
\text { hospitalization }\end{array}$ & $\begin{array}{c}\text { Number of } \\
\text { patients }\end{array}$ & Percentage (\%)* \\
\hline$<10$ days & 17 & 58.62 \\
$10-20$ days & 11 & 37.93 \\
$>30$ days & 1 & 3.45 \\
\hline Total & 29 & 100 \\
\hline
\end{tabular}

Table 4. Co-morbidity distribution

\begin{tabular}{llll}
\hline \multicolumn{1}{c}{ Comorbidities in lung } & Number of patients & Comorbidities in other organs & Number of patients \\
\hline Bronchiolitis & 2 & Heart & 18 \\
\hline Subcutaneous emphysema & 1 & Undernutrition & 4 \\
\hline Pneumomediastinum & 1 & Hypothyroid & 3 \\
\hline Pleural effusion & 1 & Down Syndrome & 3 \\
\hline Multiple bulae & 1 & Global Dev. delay & 3 \\
\hline Atelectasis lobus sup. D & 1 & Malnutrition & 2 \\
\hline & Severe wasted & 2 \\
\cline { 2 - 3 } & Acute diarrhea & 1 \\
\cline { 2 - 3 } & GERD & 1 \\
\cline { 2 - 3 } & Anemia & 1 \\
\cline { 2 - 3 } & ODS conjunctivitis & 1 \\
\cline { 2 - 3 } & Enchephalopathy & 1 \\
\cline { 2 - 3 } & FTT & 1 \\
\hline
\end{tabular}

Table 5. Use of antibiotics in pneumonia patients

\begin{tabular}{|c|c|c|c|c|c|}
\hline \multirow{2}{*}{$\begin{array}{l}\text { Types of } \\
\text { patients }\end{array}$} & \multirow{2}{*}{$\begin{array}{l}\text { Antibiotics according to Clinical } \\
\text { Practice Guidelines }\end{array}$} & \multirow[t]{2}{*}{ Selected antibiotics } & \multirow{2}{*}{$\begin{array}{l}\text { Number } \\
\text { of patients }\end{array}$} & \multicolumn{2}{|c|}{ Notes } \\
\hline & & & & $\begin{array}{l}\text { Clinical Practice } \\
\text { Guidelines } 2009\end{array}$ & $\begin{array}{l}\text { Clinical Practice } \\
\text { Guidelines } 2013\end{array}$ \\
\hline \multirow{4}{*}{$\begin{array}{l}\text { Self- } \\
\text { initiative }\end{array}$} & \multirow{4}{*}{$\begin{array}{l}\text { Ampicillin; ampicillin sulbactam } \\
\text { (Clinical Practice Guidelines 2013) } \\
\text { ampicillin-chloramphenicol; } \\
\text { ampicillin-gentamicin; sefalosporin } \\
\text { generation } 3 \text { (Clinical Practice } \\
\text { Guidelines 2009) }\end{array}$} & Ampicillin & 3 & & Met \\
\hline & & Ampicillin-gentamicin & 3 & Met & \\
\hline & & Ampicillin-chloramphenicol & 9 & Met & \\
\hline & & Ceftriaxone & 1 & Met & \\
\hline \multicolumn{6}{|l|}{ Referred } \\
\hline \multirow[t]{3}{*}{$<72$ hours } & \multirow[t]{3}{*}{ Ampicillin; ampicillin-sulbactam } & Ampicillin & 4 & & Met \\
\hline & & Ampicillin-gentamicin & 3 & Met & \\
\hline & & Ampicillin-chloramphenicol & 5 & Met & \\
\hline$>72$ hours & Cephalosporin generation 3 & Ceftriaxone & 2 & & Met \\
\hline
\end{tabular}


Table 6. Total antibiotic DDD in pediatric treatment treatment during hospitalization

\begin{tabular}{lcccccc}
\hline \multicolumn{1}{c}{ Antibiotics } & $\begin{array}{c}\text { ATC } \\
\text { Code }\end{array}$ & Route & $\begin{array}{c}\text { Total antibiotics } \\
(\mathrm{g})\end{array}$ & $\begin{array}{c}\text { DDD Value } \\
(\mathrm{g})\end{array}$ & $\begin{array}{c}\text { DDD } \\
\text { Value }\end{array}$ & $\begin{array}{c}\text { DDD/100 } \\
\text { patient days }\end{array}$ \\
\hline Ampicillin & J01CA01 & IV & 189.14 & $2013)$ & & 34.39 \\
Gentamicin & J01GB03 & IV & 2.41 & 0.24 & 10.03 & 3.65 \\
Ceftriaxone & J01DD04 & IV & 32.08 & 2 & 16.04 & 5.83 \\
Chloramphenicol & J01BA01 & IV & 40.51 & 3 & 13.50 & 4.91 \\
Cefoperazone & J01DD62 & IV & 3 & 4 & 0.75 & 0.27 \\
$\begin{array}{l}\text { Sulbactam } \\
\text { Meropenem }\end{array}$ & J01DH02 & IV & 3.36 & 2 & 1.68 & 0.61 \\
\hline *Note: Patients' LOS: 275 days & & & & & & \\
\hline
\end{tabular}

Table 7. Results of analysis on the use of antibiotics with qualitative methods

\begin{tabular}{|c|c|c|c|}
\hline Categories & Evaluation & Number & Percentage \\
\hline 0 & Antibitoic use appropriate/wise & 24 & 32.00 \\
\hline I & Antibiotic use in appropriate time & 3 & 4.00 \\
\hline II A & Antibiotic use not in appropriate dose & 31 & 41.33 \\
\hline II B & Antibiotic use not in appropriate interval & 5 & 6.67 \\
\hline II C & Antibiotic use not in appropriate route & - & - \\
\hline III A & Antibiotic use too long & 29 & 38.67 \\
\hline III B & Antibiotic use too short & - & - \\
\hline IV A & Presence of other more effective antibiotics & 9 & 12.00 \\
\hline IV B & Presence of other less toxic/safer antibiotics & 7 & 9.33 \\
\hline IV C & Presence of other more cost-saving antibiotics & 27 & 36.00 \\
\hline IV D & Presence of other antibiotics with narrower spectrum & 7 & 9.33 \\
\hline V & No indication of antibiotic use & 4 & 5.33 \\
\hline VI & Medical record data incomplete and unevaluable & - & - \\
\hline
\end{tabular}

*Note: there were 29 patients, a total of 75 antibiotics used

\section{DISCUSSION}

This study was an observational study with prospective cohort type that aims to analyze the use of antibiotics in patients with pneumonia of children admitted to the Division of Respirology, Department of Pediatrics, Dr. Soetomo Hospital, during the period February to May 2014. Analysis of the use of antibiotics using quantitative methods DDD/100 patient days and qualitative Gyssens. During the 3-month study period, found 29 patients who met the inclusion criteria, with gender distribution male 16 people $(55.17 \%)$ and 13 women $(44.83 \%)$ with the distribution of the degree of severity of illness ranging from mild to severe. Some 1 $(3.45 \%)$ patients with a diagnosis of pneumonia incoming light feebly, 8 patients $(27.59 \%)$ were diagnosed with pneumonia being sufficient condition, 16 patients $(55.17 \%)$ were diagnosed with pneumonia and a weak condition 4 people (13.79\%) were diagnosed with severe pneumonia weak condition. For most patients status is BPJS as many as 23 patients (79.31\%). With patients who come alone as many as 17 patients $(58.62 \%)$ and patient referrals as many as 12 patients $(41.38 \%)$. Type of pneumonia suffered by patients in this study were bronchopneumonia and pneumonia. Patients with a diagnosis of bronchopneumonia was the highest in the amount of $55.17 \%$; as shown in Table 5.2. Broncho-pneumonia characterized by patches of pulmonary infiltrates on that show bronchial infection accompanied by attacks on surrounding alveolar (Cunha 2009).

Long hospitalization of patients affected by disease severity, presence or absence of concomitant diseases, disorders related to the immune system (Cunha 2009). In this study, the most long hospitalization is less than 10 days, a total of 17 patients $(58.62 \%)$ followed by 10 20 days as many as 11 patients $(37.93 \%)$ and there was 1 patient $(3.45 \%)$ were hospitalized more than 32 days. Patients were hospitalized more than 32 days is 3 months old patient with a diagnosis of bronchopneumonia, malnutrition and congenital hypothyroid-ism. In addition to being diagnosed with pneumonia, children hospitalized at Respirology Division of the Department of Pediatrics, Dr. Soetomo Hospital, also experienced complications with other diseases. Most concomitant diseases are heart defects were 18 patients $(62.07 \%)$; malnutrition 4 patients (13.79\%); Down syndrome and hypothyroidism respectively 3 patients $(10.34 \%)$. The condition is a risk factor of heart abnormalities the incidence of pneumonia in children, for example in ASD oxygen-rich blood and oxygen-poor blood became mixed, mix this blood will be pumped back to the lungs so that the lungs work harder. 
When bacteria enter the bloodstream it will be easy to attack the lungs and cause pneumonia (AHA 2015). Their conditions of malnutrition, malnutrition, and child growth failure is one of the factors that influence the incidence of pneumonia. Patients Down Syndrome susceptible to pneumonia due to abnormalities of the immune system of the body, including a decrease in the number of $\mathrm{T}$ cells, a decrease in the number of B cells, loss of normal function of lymphocytes in childhood, the size of the thymus smaller than normal babies, a decrease in the percentage of $\mathrm{T}$ cells naive related $\mathrm{T}$ cell maturation cycle, sub-optimal antibody response to immunization, reduction in total and specific immunoglobulin A in saliva, decrease in neutrophil chemotaxis (Ram \& Chinen 2011).

Based clinical practice guidelines in at Respirology Division, Department of Pediatrics, Dr. Soetomo Hospital, for patients who require hospitalization may be given ampicillin or ampicillin sulbactam dose of 100 $\mathrm{mg} / \mathrm{kg} /$ day iv with a frequency of 4 times a day, while the selection of antibiotics for patient referrals from other hospitals who had received treatment at another hospital less than 72 hours given ampicillin sulbactam dose of $100 \mathrm{mg} / \mathrm{kg}$ /day with a frequency of 4 times daily. For patient referrals ever received treatment at another hospital more than 72 hours of empirical antibiotic choice among cefotaxime $200 \mathrm{mg} / \mathrm{kg} /$ day iv with the frequency of $3 \mathrm{x}$; ceftriaxone $100 \mathrm{mg} / \mathrm{kg} /$ day with a frequency of $2 \mathrm{x}$, or selection of antibiotic adapted to sputum culture/ blood cultures that exist. According to the results of research in the field as a given empirical antibiotic ampicillin, either alone or in combination use of ampicillin, ampicillin-chloramphenicol or ampicillingentamicin combination. Selection of empiric antibiotics are given based on data from epidemiological germs. Empirical antibiotic therapy re-evaluated after two or three days to see the patient's clinical condition. The use of a single ampicillin was given to 7 patients, namely ISZ, AR, YYV, BF, A, FAS, and DM. To use a combination of ampicillin-chloramphenicol was given to 14 patients (AP, Zk, YK, KI, ZA, DF, MAR, ZAP, FAP, NF, IP, R, MY, SA) and the combination of ampicillin-gentamicin was given to 6 patients $(\mathrm{ZHN}$, MFA, MR, MDAs, DAS, J). And there were 3 patients (MI, E, Zk) who received ceftriaxone as empiric antibiotics for by prior antibiotic therapy prior to referral to the Hospital Dr. Soetomo and child E in bad condition during the admission thus been giving ceftriaxone compared the combination of ampicillin.

Class of beta-lactam antibiotics or chloramphenicol is a first-line choice. And for pneumonia unresponsive to beta-lactams and chloramphenicol, may be given other antibiotics such as gentamicin, amikacin or cephalosporins according to the instructions found etiology.
Giving antibiotics combination is intended to broaden the spectrum of antimicrobial and antibiotic combinations utilize synergistic effects (Grayson et al 2010). Ampicillin will inhibit the formation of bacterial cell wall so that the bacterial cell permeability increases and would facilitate the entry of aminoglycoside into bacterial cells so that the antibacterial activity increased (Finkel 2009).

Replacement of antibiotics can be done at the first evaluation (the third day) or a second evaluation (the fifth day) if the patient does not improve clinically. Long use of antibiotics as empirical therapy the average is 3-7 days, and continued with another antibiotic (definitive therapy) after the results of cultures or bacteria that causes the infection is unknown. Antibiotic therapy can be continued for 10-14 days (Clinical Practice Guidelines 2013). In this study, the use of antibiotics for a long time varies depending on the severity of disease, complications and concomitant diseases suffered by the patient. In-creasingly mild degrees of pneumonia then the long use of antibiotics is getting shorter. Long use of antibiotics as empirical therapy the average is 4-6 days, and continued with another antibiotic (definitive therapy) after the results of cultures or bacteria that causes the infection is unknown.

Analysis of the use of antibiotics is done with quantitative methods (DDD/100 patient-days) and qualitative methods (groove Gyssens). The results of the quantitative evaluation showed that ampicillin is most widely used is 34.39 DDD/100 patient-days. Analysis using Gyssens performed on empiric antibiotics and definitive. Antibiotics are used by 29 of these patients were 75 , this is because one patient could use more than one antibiotic. Of the 75 empirical and definitive antibiotic use, $32 \%$ is appropriate, $4 \%$ is not timely, improper doses of $42.67 \%, 5.53 \%$ improper administration interval, $38.67 \%$ of administration for too long, there are $12 \%$ of other antibiotics more effective, $9.33 \%$ there are other less toxic antibiotics, 36\% there are other cheaper antibiotics, 9.33\% there are other antibiotics that spectrum is narrower, and $5.33 \%$ there is no indication of the use of antibiotics.

Category I (not timely administration of antibiotics) of $4 \%$. In this study, there were 4 cases that fall into this category, and experienced by patients $\mathrm{ZHN}$ and $\mathrm{Zk}$. In patients $Z H N$ ceftriaxone should be given when the throat swab culture results that show infection Streptococcus viridans was out on the fifth day (02.15.2014), but the new ceftriaxone given on day $9(02 / 19 / 2014)$. In patients $\mathrm{Zk}$ administration of ampicillin is not appropriate because the results of blood cultures left day-to-5 (02/17/2014) showed Staphylococcus saprophyticus 
infections that are resistant to ampicillin, but ampicillin is still given from day 7 to day 9 (19/2/14-21/2/2014), chloramphenicol administration is also inaccurate because sputum culture results 2 nd day (14/02/2014) showed Acinetobacter baumannii infections that are resistant to chloramphenicol, but chloramphenicol still be given from day 7 to day 9 th (19/2/2014-21/2/2014). For the provision of cefoperazone-sulbactam as definitive therapy (sputum culture results on day 2 which shows Acinetobacter baumannii infection) late ie new gift given on day 10 (22.02.2014) for drug stocks empty and still waiting acc of KFT.

Category II A (not appropriate for incorrect dosage) of $42.67 \%$. There are 32 antibiotic that belongs to this category. For IIA category is dominated administration of antibiotic therapy are overdose or underdose a variety of reasons why. Giving antibiotics overdose occurred in 17 underdose use of antibiotics and the condition occurs in 8 the use of antibiotics. Category IIB (not appropriate administration interval) of $6.67 \%$. There were four patients were included in this category. Patients KI and YK get chloramphenicol at intervals Award 3 times a day, whereas according to the guidelines given 4 times daily usage. In patients with MI administration of ceftriaxone given at intervals of $3 \times 80 \mathrm{mg}$ in patients beginning a new MRS lowered to $2 \times 80 \mathrm{mg}$, whereas the dose and administration interval according to the literature is $50-100 \mathrm{mg}$ per day in the 1-2x Award. As for patients $\mathrm{BF}$ patients received ampicillin therapy 3 times a day at intervals of administration, whereas according to the guidelines that are used should be given 4 times daily administration.

For guidance on the administration of antibiotics, researchers are using the interval specified in the KDP administration in 2013 made by at Respirology Division, Department of Pediatrics, Dr. Soetomo Hospital. Category III A (not appropriate for prolonged antibiotic treat-ment) amounted to $38.67 \%$. There were 29 cases of use of antibiotics that are included in this category. This category occurred in patients receiving more than 7 days. Empirical antibiotic treatment is ideal that is 3 days and the evaluation of treatment performed every 48-72 hours. If there is no clinical improvement of reimbursement antibiotic of broad spectrum antibiotics become narrow-spectrum antibiotics until the child was cured. The use of antibiotics is too long duration is also potentially increase the cost and side effects. Category IVA (not exact because no antibiotics are more effective) by $12 \%$. There are 9 uses of antibiotics in this category and the patients experienced ZHN, MFA, MR, DAS, YK, RAS and Zk. For patients ZHN throat swab culture results day 5 (02.15.2014) shows the growth of Streptococcus viridians resistant to gentamicin, but its use is still applied to the 8th day
(18.02.2014). According to data from the results of this culture antibiotic option that can be used as a substitute for gentamicin is ceftriaxone, chloramphenicol, erythromycin, and clindamycin.

MFA patient blood culture results on the 8th day (18/02/2014) shows the growth of Staphylococcus saprophyticus resistant to ampicillin but its use continued until the 16th day (02.26.2014). From the results of the culture of the antibiotic option that can be given instead of ampicillin include gentamicin, erythromycin, clindamycin. In patients YK blood culture results day $4(02 / 27 / 2014)$ shows the growth of Staphylococcus hominis are resistant to ampicillin but its use is still applied to the 8th day (03.03.2014). While the use of chloramphenicol as empirical therapy can be replaced with gentamicin that according to the results of this culture are sensitive to infecting germs. In patients $\mathrm{Zk}$ use of ceftriaxone as empirical therapy should be considered to be replaced with amikacin, ampicillin sulbactam, sulbactam sefoperazone, cotri-moxazole, imipenem, meropenem for sputum culture results on day 2 (14/02/2014) showed growth of Acinetobacter baumannii resistant ceftriaxone but its use is still applied to the 6th day (02.18.14). As for the use of ampicillin and chloramphenicol as definitive therapy should not be given until the 9th day (02.21.2014) for blood culture results right day 5 (17.02.2014) shows the growth of Staphylococcus hominis are resistant to ampicillin, with alternative antibiotics gentamicin and clindamycin sensitive is. And blood culture results left the 5 th day $(02 / 17 / 2014)$ shows the growth of Staphylococcus saprophyticuss were also resistant to ampicillin, with alternative antibiotics are tetracycline sensitive. And besides sputum culture results before the 2 nd day (14/02/2014) shows the growth of bacteria Acinetobacter baumannii resistant to chloramphenicol.

Category IV B (There are other antibiotics that are less toxic/safer) of $9.33 \%$. There were 7 the use of antibiotics that fall into this category. This relates to the selection of antibiotics that are less precise. This category dominated by the use of chloramphenicol in patients with low hemoglobin levels at or near the lower limit. Category IV C (no antibiotics cheaper) by 36\%. There are 27 the use of antibiotics in this category and is dominated by replacement of antibiotics is delayed from the intravenous route to the oral route. But in this study all intravenous antibiotics to oral replacement is done when the patient will be out of the hospital. For more details can be found in appendix 4 .

Category IV D (not appropriate because there is more narrow-spectrum antibiotics) of $9.33 \%$. There were seven cases that fall under this category and the patients experienced MFA, ZHN, YK, and Zk. MFA patient 
blood culture results on the 8th day (18/02/2014) shows the growth of Staphylococcus saprophyticus resistant to ampicillin but its use continued until the 16th day (02.26.2014). From the results of the culture of the antibiotic option that can be given instead of ampicillin include gentamicin, erythromycin, clindamycin. For patients ZHN throat swab culture results day 5 (15.02.2014) shows the growth of Streptococcus viridans resistant to gentamicin, but its use is still applied to the 8th day (18.02.2014). According to data from the results of this culture antibiotic option that can be used as a substitute for gentamicin is ceftriaxone, chloramphenicol, erythromycin, and clindamycin.

In patients YK blood culture results day $4(02 / 27 / 2014)$ shows the growth of Staphylococcus hominis are resistant to ampicillin but its use is still applied to the 8th day (03.03.2014). While the use of chloramphenicol as empirical therapy can be replaced with gentamicin that according to the results of this culture is sensitive to infecting germs. In patients $\mathrm{Zk}$ use of ceftriaxone as empirical therapy should be considered to be replaced with amikacin, ampicillin sulbactam, cefoperazone sulbactam, cotrimoxazole, imipenem, meropenem for sputum culture results on day $2(02 / 14 / 2014)$ showed growth of Acinetobacter baumannii resistant ceftriaxone but its use is still applied to the 6th day (18.02.14).

As for the use of ampicillin and chloramphenicol as definitive therapy should not be given until the 9th day (02.21.2014) for blood culture results right day 5 (17.02.2014) shows the growth of Staphylococcus hominis are resistant to ampicillin, with alternative antibiotics gentamicin and clindamycin sensitive is. And blood culture results left the 5th day (02/17/2014) shows the growth of Staphylococcus saprophyticuss were also resistant to ampicillin, with alternative antibiotics are tetracycline sensitive. Besides, sputum culture results before the 2nd day $(14 / 02 / 2014)$ shows the growth of bacteria Acinetobacter baumannii resistant to chloramphenicol. Category V (There is no indication of the use of antibiotics) amounted to $5.33 \%$. There are 4 use of antibiotics that belong to this category. For the category of improper use of antibiotics way/route of administration (IIC), the use of antibiotics is too short (IIIB) and the category of medical records are incomplete and can not be evaluated (VI) in this study amounted to $0 \%$ or no cases at all.

\section{CONCLUSION}

The selection of empiric therapy is in compliance with Clinical Practice Guidelines at Respirology Division, Department of Pediatrics, Dr. Soetomo Hospital. From the results of the quantitative analysis of the data obtained that the use of antibiotic ampicillin which most was $34.39 \mathrm{DDD} / 100$ patient-days and the results of the qualitative analysis showed that only $32 \%$ the use of antibiotics in this division are categorized appropriately.

\section{ACKNOWLEDGMENT}

The authors are grateful to the Director of Dr Soetomo Hospital, the Head and staffs of the Department of Pediatrics, as well as Medical Record staffs, Dr Soetomo Hospital, Surabaya. We are also grateful to the Dean of the Faculty of Pharmacy, Universitas Airlangga, and the Head and staffs of Clinical Pharmacy Master Program, Faculty of Pharmacy, Universitas Airlangga.

\section{REFERENCES}

American Heart Association (2015). Highlights of the 2015 AHA guidelines update for CPR and ECC. Available from http://eccguidelines.heart.org/wpcontent/uploads/2015/10/2015-AHA-GuidelinesHighlights-English.pdf. Accessed October 14, 2014

Asih R, Aini Z, Setiawati L (2011). Risk factor of bacteremia in children with pneumonia. Indonesian Journal of Tropical and Infectious Disease 2, 34-37

Bradley JS, Byington CL, Shah SS, Alverson B, Carter ER, Harrison C, Kaplan SL, Mace SE, McCracken Jr GH, Moore MR, St Peter SD, Stockwell JA, Swason JT (2011). The management of community-acquired pneumonia in infants and children older than 3 months of age: clinical practice guidelines by the pediatric infectious diseases society of America. Clinical Infectious Diseases Advance (IDSA Guidelines)

Cincinnati Children Hospital Medical Center (2005). Community Acquired Pneumonia in Children 60 days through 17 years of age - Evidence-Based Care Guideline for Children with Community Acquired Pneumonia

Clinical Practice Guidelines (2009). Clinical Practice Guidelines, Department of Pulmonology, Dr Soetomo Hospital, Surabaya

Clinical Practice Guidelines (2013). Clinical Practice Guidelines, Department of Pulmonology, Dr Soetomo Hospital, Surabaya

Cunha BA (2009). Severe community-acquired pneumonia in critical care. In: Cunha BA (ed). Infectious Diseases in Critical Care Medicine, 3th ed, Florida, CRC Press, p 164-175

Finkel R, Clark MA, Cubeddu LX (2009). Principles of antimicrobial therapy. In: Harvey RA and Champe PC (eds). Lippincott's Illustrated Re-views Pharmacology 4th ed, Philadelphia, Lippincott William \& Wilkins

Grayson LM, Kucers A, Crowe S, McCarthy J, Mills J, Mouton J, Norrby R, Paterson D, Pfaller M (2010). 
Kucers' The Use of Antibiotics Sixth Edition: A Clinical Review of Antibacterial, Antifungal, and Antiviral Drugs, Volume 1, Florida, CRC Press

Health Office, Province of East Java (2010). Profil Kesehatan Provinsi Jawa Timur Tahun 2010, Surabaya

Jesenak M, Ciljakova M, Rennerova Z, Babusikova E, Banovcin P (2011). Recurrent respiratory infections in children - definition, diagnostic approach, treatment and prevention. In: MartAn-Loeches I (ed). Bronchitis, Croatia, InTech, p 119-148

Mandell LA and Wunderink R (2010). Pneumonia. In: Kasper DL and Fauci AS (eds). Harrison's Infectious Disease, New York, McGraw-Hill Professional

Nataprawira HM, Alwi EH, Adriani N (2010). Faktor risiko morbiditas dan mortalitas pneumonia berat pada anak usia balita. Majalah Kedokteran Indonesia 60, 443-447

PrabhuDas M, Adkins B, Gans H, King C, Levy O, Ramilo O, Siegrist CA (2011). Challenges in infant immunity: implications for responses to infection and vaccines. Nature Immunology 12, 189-194

Purniti PS, Subanada IB, Kari IK, Arhana BNP, Iswari IS, Tarini NMA (2011). Surveilan pneumokokus dan dampak pneumonia pada anak balita. Sari Pediatri 12, 359-364

Ram G and Chinen (2011). Infection and immunodeficiency in down syndrome. Clin Exp Immunol 164, 9-16

Said M (2010). Pneumonia. In: Rahajoe NN, Suprayitno B, Setyanto DB (eds). Buku Ajar Respirologi Anak, edisi pertama, Jakarta, Badan Penerbit IDAI, p 350364

Setiawati L, Iskandar D, Setyoningrum RA (2012). Pneumonia. Pedoman Diagnosis dan Terapi Bagian/SMF Ilmu Kesehatan Anak, Surabaya, Fakultas Kedokteran Universitas Airlangga

Setyoningrum RA and Setiawati L (2011). Profile of community acquired pneumonia in children at Soetomo hospital Surabaya in 2007-2008. Indonesian Journal of Tropical and Infectious Disease 2, 12-14 